\title{
TWS-011 心拍変動の臨床応用
}

展示棟 /会議室3A

\author{
講演者: 榊原 雅人 (愛知学院大学)
}

心拍変動（Heart rate variability: HRV）は自律神経活動を反映する指標として受け入れられ，これ まで生理学的心理学および関連領域の研究において広く利用されている。また, HRV の増大を促すバイ オフィードバック技法（HRVBF）は抑うつや不安，不眠などストレスに関連する症状を軽減すること が報告されている。本ワークショップでは HRV の発生機序をもとにその基本的な特徵を示し, 臨床応 用の実際について具体的に解説する。

\section{第2 日 9 月26日(水) $9: 20 \sim 11: 20$}

\section{TWS-012 予防教育「社会性と情動の学習 (Social-Emotional Learning: SEL)」の理論と実際}

\author{
講演者: 宮崎＼cjkstart昭（立正大学）
}

予防教育「社会性と情動の学習 (Social-Emotional Learning: SEL)」は,「情動」の認知と扱い方なら びに他人との共感的な思いやりのある「対人関係」を学習することです。心理の国家資格である公認心 理師の業務にも心の健康に関する知識普及を図ため教育及び情報提供を行うことが規定され, 社会的に も予防教育の充実が期待されています。

Durlak ほか（2011）が行ったメタアナリシス研究では，一定の基準を満たした SEL プログラムは精 神的健康や社会的スキルと学力の向上に効果があることが科学的に実証されています。本チュートリア ル・ワークショップでは, 日本に㧍ける SELの理論と実践について演習を通じて理解を深めます。 